Article

\title{
A Framework and a Web Application for Self-assessment of Sustainable Green ICT Practices in SMEs
}

\author{
Farniba Khan ${ }^{1}$, Jari Porras ${ }^{2}$ \\ School of Engineering Science, Lappeenranta University of Technology, Finland. \\ * Correspondence: farniba.khan@student.lut.fi; jari.porras@lut.fi
}

\begin{abstract}
Green ICT has received significant attention in organizations to reduce global warming since last decade. Several maturity models have been proposed for tracking green ICT practices in organizations. Current literature shows that SMEs around the world try to follow some common strategies such as virtualization, consolidation of devices, energy efficiency and disposal of ICT equipment for greening ICT. The increasing interest for green ICT practices in organizations is not only due to the desire to attain environment-friendly atmosphere but mainly because of sustaining business goals such as cost reduction, competitive advantages and stakeholders' pressure. Nevertheless, due to the lack of green ICT knowledge, organizations, specially SMEs, tend to ignore those practices. Therefore, this research proposes a framework that provides combination of existing green and sustainable ICT maturity models by mapping them with the strategies the businesses are already following. Out of this framework, a web application has been developed that provides questionnaire for SMEs to identify their present situation of green ICT practices and guidelines for improvement. The results have been analyzed by testing the application in some SMEs of Finland and Bangladesh. Finally, a survey has been conducted to attain SMEs' perception about the possibility of sustainable development of businesses through this application.
\end{abstract}

Keywords: Green ICT; Sustainability; Green ICT maturity model; Sustainable ICT maturity model; SME;

\section{Introduction}

Information and communication technology (ICT) is considered as an essential part of businesses which results in significant amount of electricity consumption and releases carbon dioxide (CO2) that leads to greenhouse gas emissions and e-waste generation. Green ICT has been undertaken as solution to this issue. It can be referred as the actions that reduces the unfavorable effect of ICT on the nature and optimize the favorable impact ICT can possess [1].

In recent years, organizations exhibit increasing amount of consciousness about their responsibility towards environment. However, the reason behind this awareness not only depends on organizations willingness to acquire environment-friendly atmosphere, but also achieving and sustaining business goal such as cost reduction, social value of businesses and many others. Most of the large organizations have their own corporate social report for sustainability that employees are bound to follow. For example, Eco-Management and Audit Scheme (EMAS), Environmental Management System (EMS) and ISO 14001 standard, provides systematic way to enhance environmental sustainability in organizations [2]. However, small and medium sized enterprises (SMEs) are lack of those policies. Again, many models and tools have been proposed for green ICT in organizations. The models are categorized into several levels with unique characteristics which help organizations to assess their accomplished responsibilities towards environment [1]. However, organizations specially SMEs find difficulties to follow these models. The reason behind these is constraint in financial assets, absence of specialist knowledge and lack of awareness [2]. Though few studies provide information about green ICT practices in SMEs, those are not sufficient to serve 
sustainable business benefits from the practices of usage of ICT equipment that organizations are already following.

SMEs around the world try to follow some common strategies such as virtualization and consolidation, energy efficiency and disposal of ICT equipment for greening ICT and sustain their businesses. However, a framework is required so that SMEs can be concerned about their present situation of green ICT practices and able to progress from the current situation by following those strategies. Therefore, this research primarily focuses on designing a framework which provides combination of existing green ICT maturity models to facilitate benefits and environment-friendly atmosphere in SMEs. The framework maps different maturity levels from the existing models with the parameters that SMEs are following now-a-days for sustaining their businesses. Based on the framework, a self-assessment web application has been developed for SMEs that evaluates their present situation and displays improvement suggestions for sustainable green ICT practices.

To fulfill the aim of the research, design science methodology is used. It is a methodology to design and development of artefact and includes investigation of the utilization of the antiquities to explain a practical issue [3]. In this research, this methodology is comprised of several sequential steps. They are, problem identification, designing the framework, development of the web application, testing the application in SMEs and analysis of the results as presented in Figure 1.

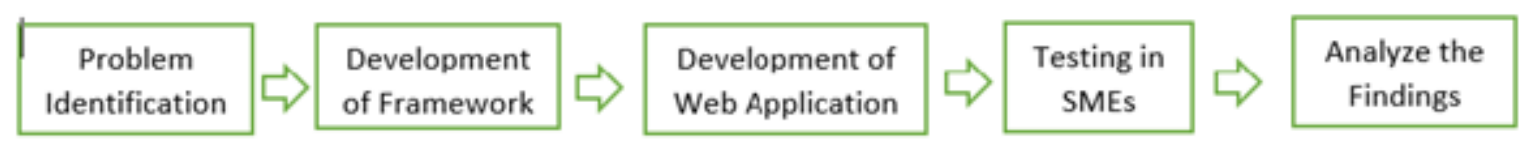

Figure 1. Entire process of the research (Design Science Methodology)

The rest of the paper is organized as follows. Section two provides the impacts of ICT and the concept of corporate social responsibility (CSR), overview of existing maturity models and tools or applications for green ICT and business drivers for implementing green ICT strategy in organizations. Section three provides an overview the of systematic literature review conducted for developing the framework. Section four explains formulation of the questionnaires out of the framework and development of the web application. The final section concludes this paper with findings, limitations and prospects for future research.

\section{Background and Related Works}

Many people considered IT infrastructures as harmful because those equipment consume noticeable amount of electricity, which eventually leads to global warming [5], Green ICT is considered as one possible solution to this problem. Nevetheless, it seems to be difficult for organizations to implement efficient green ICT strategies. Moreover, organizations often try to find out their benefits as an outcome of green ICT practices. Therefore, in this chapter the review on ICT and its impacts, corporate social responsibility and the drivers for adopting green ICT in organizations have been analyzed. In addition, existing models for green ICT maturity as well as previously implemented green ICT assessment tools or applications have been reviewed.

\subsection{ICT and its impacts}

ICT equipment, for example, computers, laptops, printers, and servers, are considered as an essential part of the current business world. The use of ICT is growing with the rapid advancement of digitalization and web-based services. However, the increasing usage of ICT equipment contributes to remarkable amount of electricity consumption and produce electronic wastes (e-waste) that eventually generate green-house gas emission [2]. Moreover, according to the report of Smarter 2030, ICT can empower a $20 \%$ diminishment of worldwide CO2 emissions by 2030, holding outflows at 2015 levels. This implies it can conceivably maintain a tradeoff between financial thriving and ecological protection. The exploration demonstrates the ICT division's discharges 
"impression" is relied upon to decline to $1.97 \%$ of worldwide outflows by 2030 , contrasted with $2.3 \%$ out of 2020 [4].

Green ICT is considered as a possible solution to this problem. It can be defined as a combination of actions that reduces the negative impact of ICT and enhances the positive impact ICT can possess on environment. In other words, it can refer as any action that consider the direct, indirect and systemic influence of ICT on the environment [1]. In an organization, it indicates environment friendly and sustainable practices while using ICT equipment. The practices of green ICT result in reducing carbon emissions from ICT resources, therefore provides an environment friendly atmosphere. The practices of efficient usage of ICT equipment include turning off computers after office hour, disposal of electronic wastes (e-wastes) and many others in an organization [5].

\subsection{Corporate Social Responsibility}

The idea and business consciousness of corporate social responsibility (CSR) has advanced extensively since it initially developed in the 1950s [6]. In [7], Holmes and Watts of the World Business Council for Sustainable Development gave a statement of CSR as the procedure with obligation by business to act ethically and add finance related change while upgrading the individual fulfillment of the workforce, their families and additionally of the neighborhood network and society at large'. Lying behind this definition is the conviction that the organization's primary target as characterized in the field of corporate fund - amplifying investor esteem - is not sustainable on the grounds as it overlooks different characters (or 'stakeholders', for example, creditors, customers, debtors, environmental interests and future generations) [8].

The most well-known statement of sustainable development is referred to as "meet the needs of the present without compromising the ability of future generations to satisfy their own needs" [9]. Moreover, it needs to fulfill the three dimensions, which are Moreover, it needs to fulfill the three dimensions, which are the social, economic and environmental [9]. CSR is, however, an expansion of the hypothesis of sustainable development. It is the act of the hypothesis of reusing resources, which expects organizations to modify the activity method of 'Benefit arranged', yet to accomplish the financial benefits, social advantage and ecological benefit. Therefore, the more CSR the companies possess can bring good financial and social benefit. In the meantime, CSR can upgrade the organization's social reputation. However, completion of social responsibility depends largely upon organization's profitability. The organizations have more financial capacity to do CSR towards the administration, the workers, social welfare and nature if the financial benefit grows higher [10]. Therefore, large companies possess more CSR reports for sustainability for employees than SMEs.

\subsection{Drivers for adopting Green ICT practices in organizations}

From the motivation of CSR, organizations, now-a-days, are bound to take systematic approaches to protect the environment. This responsibility is fulfilled by practicing and encouraging the employees about environment-friendly acquisition of information technologies. Moreover, performing such responsibilities towards environment enables integration of different organizations for solving social and environmental issues in their business tasks, in addition satisfies needs of their stakeholders [11].

As per a study in [12], six benefits had found out when respondents clarify the reason behind their embracement in green ICT activities. Those are: reducing power consumption, diminished consumables utilization, expanded benefits for the organization, reducing costs or speculations, taking care of stakeholders' requirements and acknowledging credits or discounts from nearby utilities. Controlling expenses is the most prominent factor driving execution crosswise over activities: the capacity to reduce utilization of power and different consumables, both of which are picked by the greater part of respondents. Strikingly, activities with the greatest reception have diminishing power and consumables use are found as the most popular explanation behind usage. This is not astounding, since diminishments in power and consumables, for example, paper and fuel convert into prompt cost-reduction [13]. 


\subsection{Existing maturity models for green ICT}

Many maturity models or frameworks exist for green ICT. Some of the well-known models are, Green IT Readiness Framework, Green IS Framework, Holistic approach to Green IT, SICT maturity model, SURF Green ICT maturity model.

Differences exist among these frameworks and each of them has some limitations that this research aims to solve. For example, the Green IT Readiness framework is composed of five segments, Green IT Attitude, Policy, Practice, Technology, and Governance. These segments are useful for estimating Green IT capabilities in an organization. One of the limitations of the framework is that the maturity level cannot be measured. Moreover, it does not present predefined procedures to take since it is more suitable to display an organization in what aspects it is ready for green IT and in which it is not. Considering the sustainability aspects, social aspects are absent in these components since this framework is mainly focused on environmental issues. Again, several different domains such as, people, processes and green IT are presented in Green IS framework. Moreover, it satisfies all three main dimensions of sustainability (environmental, economic and social). However, any detailed information about the usability in real life are missing in this framework [14].

Murugesan and Gangadharan have proposed a framework to deal with the ecological effects of IT thoroughly and proficiently. This framework consists of six domains to achieve sustainability in green IT. They are green design of IT systems, green manufacturing of IT systems, green use of IT systems, green IT strategies and policies and green standards and metrics. The framework presents how these elements are interconnected with each other. Moreover, it fulfills three main dimensions of sustainability. However, this framework fails to provide any measurement or a maturity level and validation. In addition, the usability of the framework in an investigation or what should be the result of applying is not mentioned [14].

Another well-known model is SICT maturity model, provides an essential tool to assess and arrange the maturity of sustainability of organizations [15]. It contributes to an explanatory value-based model for assessing, arranging and planning for SICT capabilities [16]. The framework has direct and indirect effect on the three main dimensions of sustainability- environmental, social and economic [14]. To understand the business priorities and main drivers for SICT in an organization, interviews have been conducted with senior management authority. It is recommended that both IT and other departments should take necessary actions for sustainable development of IT. Moreover, medium-sized companies' employees need to be involved in making decisions for developing sustainability capabilities. Furthermore, sustainability should not be a way for reducing cost, however, the whole organization requires to be educated to improve the sustainability of IT [14].

SURF Green ICT Maturity Model (SGIMM) is a tool developed for higher educational institutions. It is a self-evaluation tool for higher education foundations and associations, assessing the abilities of green ICT in ecological effect challenging. The model consists of several parameters that allows organizations for self-assessing their organization [17]. The categorizes are, green ICT in the association, greening of ICT, greening of activities with ICT, and greening of essential procedures with ICT. Each category has several attributes. Each attribute has a maturity level with a description of what it contains. The main aim of this framework is to cultivate an inside exchange in organizations, encouraging concurrence on analysis of the present circumstance (the general development level), and defining development activities [18]. The model has been evaluated in a survey of green ICT experts [19]. The center of this survey was to decide the importance of the attributes used in the framework and whether their illustration was right. The framework covers environmental, social and economic dimensions, where the social dimension, is directly involved with only 'community collaboration.' For the improvement of the SGIMM framework, it is suggested that based on a combination of interviews, common sense and literature, the categories to be added need to be determined and later it can be added to the SGIMM [20].

From the description of the frameworks, it has been found that, most of the frameworks deal with ecological effects of IT and useful for estimating Green IT capabilities in organizations. 
However, each of the framework is different from the other and some limitations exist. For example, some of them are unable to measure maturity level of organization, while some of them fail to provide any validation information and how to use the framework in real life. Again, in some of the frameworks, no exploration has been made for extra components of IT which is useful since IT is growing rapidly. Therefore, there is a need for a framework that satisfies all these features.

\subsection{Existing application for Green ICT assessment in SMEs}

In [21], a framework was chosen from literature review for green ICT in SME and a self-assessment application was proposed out of that framework. Few questions were developed, and the answers were given marks based on the choice. However, this application is inadequate to provide feedback on improvement of green ICT practices in SMEs. Therefore, the authors recommend testing this application on more organizations and documentary evidence for validation in future.

Another self-assessment application for evaluating environmental responsibility of SMEs was presented in [2]. A set of questionnaires was prepared for determining the level and recommendation was suggested to go to the next level. However, this application mainly focused on the environmental aspect of sustainability. Moreover, country-wise and organization type wise variation was not considered.

In addition, many other applications have proposed in [22], [23], [24] to investigate for the evaluation of organization's green ICT initiatives. These tools provide a basic guideline of the effect of green ICT in businesses. However, these tools are not sufficient to track progress for improving green ICT practices in organizations [25].

\section{Development of Green ICT framework}

The systematic literature review (SLR) methodology was executed for data collection, extraction, investigation, and synthesis [26] for developing the framework for assessing green ICT practices in an SME. According to the statement of Kitchenham and Charters, SLR is "a means of identifying, analyzing and interpreting all available data relevant to particular research question or topic area, or phenomenon of interest" in an impartial style. Three stages are followed for the SLR approach: planning, executing and reporting the review [27].

Four different queries were executed to the selected databases mentioned in table 1 . The main criteria for selecting these papers was to find different existing maturity models and the approaches that organizations are following for green ICT. Since it is not possible to go through the large number of papers, therefore, at first, the title of the paper is skimmed to find useful papers. Next the abstract, then conclusion and at the end the content of those articles have been skimmed that focuses on green ICT in organizations. Moreover, AND and OR logical operations have been performed to find appropriate papers that focus on either Green or Sustainable ICT maturity model in organizations. Furthermore, after careful observations from those papers, 21 papers were finally selected for detailed data extraction for designing the framework. The finally selected papers are not only from the last column, but also selected from other columns accoding to the relevancy with the research.

Table 1. Search Result from databases

\begin{tabular}{|c|c|c|c|c|c|}
\hline Database & $\begin{array}{l}\text { Green } \\
\text { ICT }\end{array}$ & $\begin{array}{l}\text { Green ICT in } \\
\text { organizations }\end{array}$ & $\begin{array}{l}\text { Green ICT } \\
\text { maturity } \\
\text { model }\end{array}$ & $\begin{array}{l}\text { Sustainable } \\
\text { ICT maturity } \\
\text { model }\end{array}$ & $\begin{array}{l}\text { Green } \\
\text { ICT I Sustainable } \\
\text { ICT + maturity } \\
\text { model } \\
\text { organizations }\end{array}$ \\
\hline IEEE Explorer & 760 & 41 & 5 & 12 & 5 \\
\hline Springer & 11,659 & 5,934 & 665 & 1216 & 11 \\
\hline ScienceDirect & 7,827 & 3,348 & 476 & 986 & 2 \\
\hline Emerald Insight & 1038 & 932 & 193 & 784 & 3 \\
\hline
\end{tabular}


The data collected from these papers are green and Sustainable ICT maturity levels, ICT equipment that are used in majority of the organizations and the strategies that SMEs are following for green ICT practices while using ICT equipment. These data have been used to design the framework.

Investigation of literature based on the two research questions for designing the framework are as follows:

Q1) What are the green ICT maturity models presented in the literature?

The green ICT maturity model is specified maturity in various levels each described by a particular characteristics. It generally refers to maturity of five levels, starting from level 1 to level 5, where level 1 is the lowest and level 4 is the highest level. In ascending order, these levels are defined as initial, managed, defined, quantitatively managed and optimizing respectively. The advantage of these maturity models is that they permits benchmarking in various enterprises[21]. Foogooa, Bokhoree and Dookhitram analyzed several Green ICT maturity models and based on the reviews, proposed a general green ICT model. The model consists of different levels where the lower indicates no awareness regarding organizations therefore no plan or implementation of green ICT strategies and higher level is set to accomplish goals such as include measured metrics and many others [21].

On the other hand, in [25], the paper shows a demonstration of sustainable development for project management in organizations. In view of the ideas of sustainability, the model evaluates the level of sustainability as assets, business approaches, plan of action and items/administrations.

Q2) What are the parameters that the organizations follow for green ICT practices?

Several common ICT equipment that almost every organization possesses are desktop pc, laptop, monitors, thin clients, printers and multifunctional devices [28]. Besides, an outline of green ICT adoption approaches in Small and Medium Sized Enterprises (SMEs) around the globe is shown in [29] where several parameters are server virtualization and consolidation, existing server room redesigns, assembling new server room, estimation of energy consumption by ICT equipment, power management of PC and printer, consolidation of printers, remote conferencing, and IT hardware reusing and disposing. The effect of actualizing these procedures help organizations to diminish cost and thus reduce greenhouse gas emissions. Moreover, common strategies and equipment that are used by almost all organizations are listed in [30]. Eight parameters have been finalized based on those for developing the framework. They are: power management of computers, reduction of computers for power management, power management of imaging equipment (printers/scanners/photocopiers), paper saving from ICT equipment, power management of video conferencing suite, IT load reduction management of server, cooling management of ICT equipment and management of e-waste disposal.

From the search results of table-1, supporting texts have also been gathered for each of the eight parameters to develop the framework. Reference texts for each of the parameters have been presented in table- 2 .

Table 2. Reference texts for framework designing with sources

\begin{tabular}{llc} 
Parameter & Reference Texts & Sources \\
\hline Power & Turning off computers during inactivity is the best option for & {$[29]$,} \\
management of & power and cost saving. & {$[30]$,} \\
computers & Plugging computers into electrical outlets consumes energy. & {$[31]$} \\
& Therefore, it is recommended to unplug computers from & \\
& electrical outlets when turned off. & \\
& An automated shutdown software is required for those who & \\
& forget to shut down computers. \\
& Screensaver is enabled to decrease energy consumption by & \\
\hline
\end{tabular}


computers. Nonetheless, screensaver consumes same amount of energy when the computers are kept on in active mode. It is suggested to turn off computers when inactivity is observed. Moreover, the Climate Savers Computing Initiatives proposes setting display and system to put in low power mode and sleep after certain time of latency. For better user experience with optimized energy usage, Energy Star suggests to enable display and system to enter sleep mode after 5 to 20 minutes and 30 to 60 minutes respectively.

\begin{tabular}{|c|c|}
\hline $\begin{array}{l}\text { Reduction of } \\
\text { computers for } \\
\text { power } \\
\text { management }\end{array}$ & $\begin{array}{l}\text { It is desirable to have the ratio of employee and computer set } \\
\text { as 1:1 in an organization for less power consumption. Desktop } \\
\text { PCs consume more energy than laptops. Thin client PC } \\
\text { consumes five times less energy consumption than desktop } \\
\text { PC since it has few parts than desktop PC and generates low } \\
\text { heat. }\end{array}$ \\
\hline $\begin{array}{l}\text { Management of } \\
\text { powering off } \\
\text { imaging } \\
\text { equipment } \\
\text { (printers, } \\
\text { scanners, } \\
\text { photocopiers) }\end{array}$ & $\begin{array}{l}\text { Consolidation of imaging equipment can reduce electricity } \\
\text { cost significantly. } \\
\text { To automatically turn off printers/scanners/photocopiers } \\
\text { when not in use, smart power strips are used for electricity } \\
\text { consumption reduction. } \\
\text { Organizations possess instructions set for employees to turn } \\
\text { on power saving attributes on their equipment. In some } \\
\text { organizations, equiment has achieved Energy star } \\
\text { certification label which means that those equipment are } \\
\text { designed to save energy. Therefore, employees encounter less } \\
\text { energy when they use these equipment by automatically set to } \\
\text { enter low-power mode during inactivity. }\end{array}$ \\
\hline
\end{tabular}

\begin{tabular}{|c|c|c|}
\hline $\begin{array}{lr}\text { Paper } & \text { and } \\
\text { energy } & \text { saving } \\
\text { from } & \text { ICT } \\
\text { equipment } & \end{array}$ & $\begin{array}{l}\text { According to a study in the universities in Kenya, } \\
\text { organizations have centralized printers and they efficiently } \\
\text { manage printing requests. It is recommended that the ratio of } \\
\text { number of employees and printers, scanners, photocopiers in } \\
\text { an office should be } 10: 1 \text {. Therefore, it is suggested to } \\
\text { consolidate single printers, scanners, copiers into } \\
\text { multi-functional equipment and make the equipment easily } \\
\text { accessible by all employees. } \\
\text { Energy star label can be found in many equipment. Energy } \\
\text { star printers reduce paper consumption by automatically } \\
\text { print on both side of the paper. However, it is recommended } \\
\text { that if the printer carries automatic duplexing setting, then } \\
\text { users are advised to change that to double-sided printing to } \\
\text { save energy. Moreover, locked printing feature are suggested } \\
\text { to be enabled in printers and other imaging equipment. }\end{array}$ & $\begin{array}{l}{[33],} \\
{[28],} \\
{[12],} \\
{[30]}\end{array}$ \\
\hline $\begin{array}{l}\text { Power } \\
\text { Management of } \\
\text { video } \\
\text { conferencing } \\
\text { suite }\end{array}$ & $\begin{array}{l}\text { According to the findings in one reseach paper, it is suggested } \\
\text { to the employees to turn off video conferenting suite at night } \\
\text { because in another study it has been exhibited that during } \\
\text { standby mode, video conferencing suite consumes significant } \\
\text { amount of energy that is not visible sometimes. } \\
\text { It is advisable to change screens to standby mode in the } \\
\text { middle of calls instead of displaying a static picture since } \\
\text { studies have found that the screen consumes highest amount } \\
\text { of energy in a video-conferencing suite. } \\
\text { Moreover, the paper also recommends that investment in }\end{array}$ & [34] \\
\hline
\end{tabular}

[30],

from ICT manage printing requests. It is recommended that the ratio of an office should be 10:1. Therefore, it is suggested to consolidate single printers, scanners, copiers into multi-functional equipment and make the equipment easily accessible by all employees.

Energy star label can be found in many equipment. Energy users are advised to save energy. Moreover, locked printing feature are suggested to be enabled in printers and other imaging equipment.

According to the findings in one reseach paper, it is suggested Management of to the employees to turn off video conferenting suite at night because in another study it has been exhibited that during conferencing standby mode, video conferencing suite consumes significant amount of energy that is not visible sometimes.

It is advisable to change screens to standby mode in the middle of calls instead of displaying a static picture since studies have found that the screen consumes highest amount Moreover, the paper also recommends that investment in 
power control equipment with this type of devices can aware employees about the advantages of turning off equipment after office hour and during weekend.

In addition, automated the shutdown process in required to powering down video conferencing suite after certain time of inactivity.

IT Load According to a study conducted in US, around 25\% of Reduction moderate size organizations have officially finished some

Management of type of server consolidation or virtualization, and another [35] Server half are anticipating these activities within a year.

By combining unique, independent servers to a solitary physical server, those servers can work more efficiently and decline energy expenses up to $40 \%$.

It is observed that $15 \%-30 \%$ servers are left unused in a data center. However, they consume energy.

The utilization rate of a usual server is about 5 to 15 percent. However, it consumes full power.

Therefore, energy star rated servers are recommended to used by organizations that draws 30 percent less energy than a normal server.

Cooling According to the responses of interviewees in the universities management of of Kenya, it has been found that virtualization or rack servers ICT equipment enablement is encouraged in the organization. Some other responded that ICT equipment are kept at lowest attainable temperature. Moreover, they stated that instructions have been given to them for cooling those equipment. On the other hand, some interviewees replied they possess some physical servers in their organization.

Management of By donating electronics where the lifecycle of the equipment E-waste has not finished yet can be a good option. Moreover, reusing disposal is an option to reduce e-waste pollution. Computer Aid international is a charity that set specific container for [28], disposing electronic equipment from regular waste in office. The European Community WEEE (Waste Electrical and Electronic Equipment) directive has set specific recommendation about reusing wasted electrical equipment. In compliances with the producer pays guideline, the WEEE orders to put the duty on the producer and sellers of electrical equipment to gather and reuse electronic equipment.

There are numerous electronics reusing associations which figure out how consumables can be reused.

An investigation was led in India on 100 people of several professions to comprehend their consciousness about e-waste managing. The greater part of the general population in study use different types of electronic equipment where everyone except $1 \%$, of the interviewees were having PC or tablet pc. Again, other than 3\% all the respondent were having mobile phones alongside different gadgets. However, at most $19 \%$ of interviewees know to manage their electronic devices in which $7 \%$ stated to return it to the producer and $12 \%$ said to go for reusing to some association. $21 \%$ were of conclusion to dispose the electronics as regular waste. $23 \%$ of people 
concurred that they don't have any knowledge about how to

process e-waste.

The definition of a framework can be defines as a collection of theoretical aspects arranged in a manner that more systematic knowledge of the occurence can be achieved [38]. This research proposes a five level of maturity framework based on the suggested framework in [20], [15], [17], [21] for SMEs. From the lower level, the levels are defined as initial, repeatable, defined, quantitatively managed and optimized respectively. The characteristics of each the levels are given below in table 3:

Table 3. Characteristics of the levels of the framework

\begin{tabular}{ccl}
\hline Level & State & \multicolumn{1}{c}{ Description } \\
\hline 0 & Initial & No awareness, no implementation of Green ICT actions \\
\hline 1 & Repeatable & $\begin{array}{l}\text { Minimal awareness of Green ICT, immature initiatives than } \\
\text { limits the non-sustainable actions. }\end{array}$ \\
\hline 2 & Defined & $\begin{array}{l}\text { Informal initiatives of Green ICT strategies and elimination of } \\
\text { the cause of non-sustainable effects. }\end{array}$ \\
\hline 3 & $\begin{array}{c}\text { Quantitatively } \\
\text { Managed }\end{array}$ & $\begin{array}{l}\text { Formal, measured and control Green ICT strategies for } \\
\text { favorable sustainability effects }\end{array}$ \\
\hline 4 & Optimized & $\begin{array}{l}\text { Optimized environmental impacts for sustainable } \\
\text { development }\end{array}$ \\
\hline
\end{tabular}

The framework has been developed by mapping different levels and parameters that businesses follow for Green ICT practices. The criteria for each level of the parameters in table 4 have been set based the selected set of literature presented in table 2 . The left column displays parameters and the top row represents level number. Moreover, description of each level have also specified in table 4 .

Table 4. The detailed framework

\begin{tabular}{|c|c|c|c|c|c|}
\hline Parameter & Level 0 & Level 1 & Level 2 & Level 3 & Level 4 \\
\hline $\begin{array}{l}\text { Power } \\
\text { manageme } \\
\text { nt of } \\
\text { computers }\end{array}$ & $\begin{array}{l}\text { Computer } \\
\mathrm{s} \text { are not } \\
\text { turned off } \\
\text { manually } \\
\text { after office } \\
\text { hour. No } \\
\text { screen-sav } \\
\text { er, } \\
\text { standby, } \\
\text { sleep, } \\
\text { automated } \\
\text { software is } \\
\text { used to } \\
\text { turn off } \\
\text { computers } \\
\text {. }\end{array}$ & $\begin{array}{l}\text { Computers } \\
\text { are turn off } \\
\text { manually } \\
\text { only after } \\
\text { office hour. } \\
\text { Active } \\
\text { screensaver } \\
\text { mode is } \\
\text { enabled } \\
\text { when } \\
\text { inactivity is } \\
\text { observed. } \\
\text { Computers } \\
\text { are not set to } \\
\text { sleep mode. }\end{array}$ & $\begin{array}{l}\text { Computers are } \\
\text { turned off } \\
\text { manually after } \\
\text { office hour. } \\
\text { Active } \\
\text { screensaver is } \\
\text { removed. } \\
\text { Display and } \\
\text { the system } \\
\text { enter to sleep } \\
\text { mode but the } \\
\text { time to enter } \\
\text { the sleep } \\
\text { mode is not } \\
\text { known. }\end{array}$ & $\begin{array}{l}\text { Employees turn } \\
\text { off devices } \\
\text { manually when } \\
\text { not in use for } \\
\text { certain time. } \\
\text { Display set to } \\
\text { enter sleep } \\
\text { mode more than } \\
20 \text { minutes of } \\
\text { inactivity. } \\
\text { Computers are } \\
\text { set to enter } \\
\text { system standby } \\
\text { or sleep mode } \\
\text { after more than } \\
60 \text { minutes of } \\
\text { inactivity. }\end{array}$ & $\begin{array}{l}\text { Automated } \\
\text { shutdown } \\
\text { software turns off } \\
\text { computers } \\
\text { automatically after } \\
\text { certain time set } \\
\text { period. Display } \\
\text { enters sleep mode } \\
\text { after } 5 \text { to } 20 \\
\text { minutes } \\
\text { inactivity of and } \\
\text { system enters } \\
\text { standby or sleep } \\
\text { mode after } 30 \text { to } 60 \\
\text { minutes. }\end{array}$ \\
\hline $\begin{array}{l}\text { Reduction } \\
\text { of number } \\
\text { of } \\
\text { computers }\end{array}$ & $\begin{array}{l}\text { Number of } \\
\text { computers } \\
\text { used by } \\
\text { each }\end{array}$ & $\begin{array}{l}\text { Multiple } \\
\text { desktop } \\
\text { PCs/laptops } \\
\text { are allocated }\end{array}$ & $\begin{array}{l}\text { Multiple } \\
\text { laptops are } \\
\text { allocated for } \\
\text { each employee }\end{array}$ & $\begin{array}{l}\text { Only one laptop } \\
\text { is allocated for } \\
\text { each employee. }\end{array}$ & $\begin{array}{l}\text { Thin client PCs or } \\
\text { Energy star rated } \\
\text { devices are used. }\end{array}$ \\
\hline
\end{tabular}




\begin{tabular}{|c|c|c|c|c|c|}
\hline $\begin{array}{l}\text { for power } \\
\text { manageme } \\
\text { nt }\end{array}$ & $\begin{array}{l}\text { employee } \\
\text { has not } \\
\text { considered }\end{array}$ & $\begin{array}{l}\text { for each } \\
\text { employee }\end{array}$ & $\begin{array}{l}\text { no desktop PC } \\
\text { exists. }\end{array}$ & & \\
\hline $\begin{array}{l}\text { Power } \\
\text { Manageme } \\
\text { nt of } \\
\text { Imaging } \\
\text { Equipment } \\
\text { (Printers, } \\
\text { Scanners, } \\
\text { Photocopie } \\
\text { rs) }\end{array}$ & $\begin{array}{l}\text { Devices } \\
\text { are not } \\
\text { turned off } \\
\text { after office } \\
\text { hour. No } \\
\text { low power } \\
\text { mode or } \\
\text { sleep } \\
\text { mode is } \\
\text { enabled in } \\
\text { devices }\end{array}$ & $\begin{array}{l}\text { Devices are } \\
\text { turned off } \\
\text { manually } \\
\text { after office } \\
\text { hour and } \\
\text { enter to low } \\
\text { power mode } \\
\text { after certain } \\
\text { time of } \\
\text { inactivity. }\end{array}$ & $\begin{array}{l}\text { Devices are } \\
\text { turned off } \\
\text { manually after } \\
\text { office hour } \\
\text { and enter to } \\
\text { sleep mode } \\
\text { after certain } \\
\text { time in low } \\
\text { power mode } \\
\text { during } \\
\text { inactivity }\end{array}$ & $\begin{array}{l}\text { Timer switches } \\
\text { are used to turn } \\
\text { off devices } \\
\text { during inactivity }\end{array}$ & $\begin{array}{lr}\text { Smart power } \\
\text { strips are used for } \\
\text { power } \\
\text { management } \\
\text { as, turn } \\
\text { devices, off } \\
\text { power and } \\
\text { mode. }\end{array}$ \\
\hline $\begin{array}{l}\text { Paper and } \\
\text { energy } \\
\text { saving } \\
\text { from ICT } \\
\text { equipment }\end{array}$ & $\begin{array}{l}\text { Do not } \\
\text { have any } \\
\text { practices } \\
\text { for paper } \\
\text { saving. }\end{array}$ & $\begin{array}{l}\text { Savings } \\
\text { made by } \\
\text { presetting } \\
\text { duplex, } \\
\text { booklet and } \\
\text { greyscale } \\
\text { defaults. }\end{array}$ & $\begin{array}{l}\text { Use "Print on } \\
\text { collect"/centra } \\
\text { lizing } \\
\text { equipment } \\
\text { other than } \\
\text { private use } \\
\text { facility shared } \\
\text { by employees. }\end{array}$ & $\begin{array}{l}\text { Locked printing } \\
\text { feature } \\
\text { enabled. }\end{array}$ & $\begin{array}{l}\text { Energy star rated } \\
\text { devices are used. } \\
\text { Replace devices } \\
\text { with network } \\
\text { multi-functional } \\
\text { devices (combined } \\
\text { printers/copiers/sc } \\
\text { anners) }\end{array}$ \\
\hline $\begin{array}{l}\text { Power } \\
\text { Manageme } \\
\text { nt of Video } \\
\text { Conferenci } \\
\text { ng Suite }\end{array}$ & $\begin{array}{l}\text { Video } \\
\text { conferenci } \\
\text { ng suite is } \\
\text { not turn } \\
\text { off after } \\
\text { office } \\
\text { hour. }\end{array}$ & $\begin{array}{l}\text { Video } \\
\text { conferencing } \\
\text { suite set to } \\
\text { standby } \\
\text { mode after } \\
\text { office hour. }\end{array}$ & $\begin{array}{l}\text { Manually } \\
\text { shuts down } \\
\text { the video } \\
\text { conferencing } \\
\text { suite after } \\
\text { office hour. }\end{array}$ & $\begin{array}{l}\text { Screens enter } \\
\text { standby mode in } \\
\text { between calls } \\
\text { than displaying } \\
\text { static image. }\end{array}$ & $\begin{array}{l}\text { Automatically } \\
\text { shuts down by } \\
\text { using power } \\
\text { management } \\
\text { equipment with } \\
\text { devices which can } \\
\text { be turned on by } \\
\text { user after office } \\
\text { hour. }\end{array}$ \\
\hline $\begin{array}{l}\text { IT Load } \\
\text { Reduction } \\
\text { Manageme } \\
\text { nt of Server }\end{array}$ & $\begin{array}{l}\text { Several } \\
\text { single } \\
\text { independe } \\
\text { nt servers } \\
\text { with low } \\
\text { utilization } \\
\text { or no } \\
\text { server } \\
\text { exists }\end{array}$ & $\begin{array}{l}\text { Decommissio } \\
\mathrm{n} \text { of unused } \\
\text { servers }\end{array}$ & $\begin{array}{l}\text { Aware or plan } \\
\text { of } \\
\text { virtualization/ } \\
\text { rack rervers } \\
\text { but r no } \\
\text { implementatio } \\
\text { n }\end{array}$ & $\begin{array}{l}\text { Consolidate } \\
\text { lightly used } \\
\text { servers to } \\
\text { independent } \\
\text { servers to run } \\
\text { different } \\
\text { workloads to a } \\
\text { single physical } \\
\text { server e.g., } \\
\text { virtualization. }\end{array}$ & $\begin{array}{l}\text { Energy efficient } \\
\text { server is used }\end{array}$ \\
\hline $\begin{array}{l}\text { Cooling } \\
\text { manageme } \\
\text { nt of ICT } \\
\text { equipment }\end{array}$ & $\begin{array}{l}\text { Do not } \\
\text { have any } \\
\text { plan for } \\
\text { cooling } \\
\text { manageme } \\
\text { nt of ICT } \\
\text { equipment }\end{array}$ & $\begin{array}{l}\text { Planning but } \\
\text { no } \\
\text { implementati } \\
\text { on }\end{array}$ & $\begin{array}{l}\text { Enclosures are } \\
\text { used on all } \\
\text { sides of server } \\
\text { racks to lessen } \\
\text { the blending } \\
\text { of cool and hot } \\
\text { air. }\end{array}$ & $\begin{array}{l}\text { Different speed } \\
\text { fan drives are } \\
\text { utilized in AC } \\
\text { units for cooling. }\end{array}$ & $\begin{array}{l}\text { Efficiently deploy } \\
\text { air-flow } \\
\text { maintenance } \\
\text { devices such as } \\
\text { structured cabling } \\
\text { systems, diffusers } \\
\text { and blanking } \\
\text { panels. }\end{array}$ \\
\hline
\end{tabular}




\begin{tabular}{|c|c|c|c|c|c|}
\hline $\begin{array}{l}\text { Manageme } \\
\text { nt of } \\
\text { E-waste } \\
\text { disposal }\end{array}$ & $\begin{array}{l}\text { E-wastes } \\
\text { are } \\
\text { dis-posed } \\
\text { with } \\
\text { regular } \\
\text { trash }\end{array}$ & $\begin{array}{l}\text { E-wastes are } \\
\text { disposed in } \\
\text { the } \\
\text { appropriate } \\
\text { container, } \\
\text { separating } \\
\text { from general } \\
\text { waste. }\end{array}$ & $\begin{array}{l}\text { Sell to second } \\
\text { hand shop or } \\
\text { donate }\end{array}$ & $\begin{array}{l}\text { Return to the } \\
\text { producer/suppli } \\
\text { ers from where } \\
\text { the device was } \\
\text { purchased }\end{array}$ & $\begin{array}{l}\text { Go for recycling to } \\
\text { WEEE recovery } \\
\text { business } \\
\text { organization in the } \\
\text { locality. } \\
\text { Organizations are } \\
\text { inclined to use } \\
\text { Energy Star rated } \\
\text { products. }\end{array}$ \\
\hline
\end{tabular}

\section{Development of GREENSME Application}

To use the information in the framework presented in table 4, in real SMEs, a web application "GreenSME" has been developed based on the framework. The objective of the application is to calculate the green ICT practice level of organization and suggest recommendation to go to the next level by considering the organization's present situation. Therefore, a set of survey questions that calculates the green ICT practice level, based on the description presented in the framework was developed. It is intended to be used by IT Specialists or CEOs of SMEs to assess their status of green ICT practices. Moreover, based on the status, the application provides recommendations on how to improve by suggesting immediate actions to perform and guidelines to go to the next level.

The application consists of set of questions. These questions are based on the parameters and descriptions presented in table 4. Questions for all parameters, have been given in the application which can be found at https://greenorg-farniba.c9users.io/. Since, the questions need to be match with the description of the levels of the framework, therefore, closed-ended questions were selected so that respondents can choose from pre-specified answer choices which are easy to quantify. To keep respondents focused, limited number of questions have been asked and the application requires all questions to be answered to avoid missing key data [39]. A simple logic has been developed to calculate the current level of green ICT practices of SME from the selected options of the questions. The logic is presented in a diagram in figure 2 :

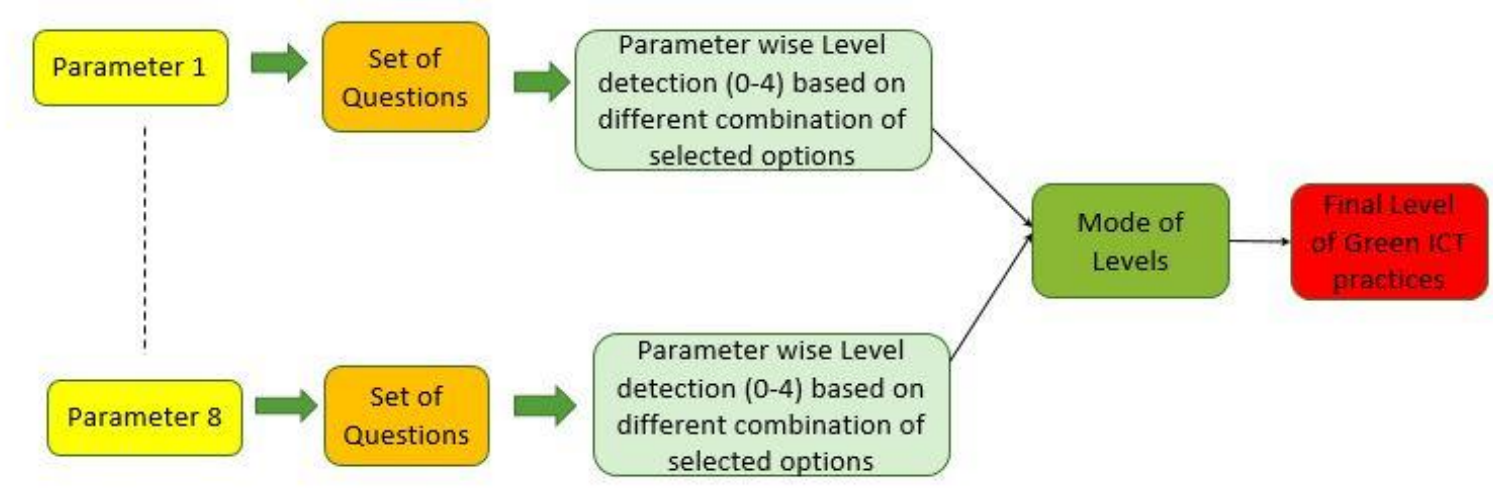

Figure 2. Calculation logic for Green ICT practice level detection

As shown in figure 2, a set of questions are set for each of the parameter. Each option in a question has assigned a level that matches with the framework. Different combination of selected option for each parameter provides level ranging from 0-4. For example, considering the first parameter, "power management of computers", four questions are set. A scenario has been given as an example for the calculation of this parameter in table 5.

Table 5. Sample Responses of an SME for "Power Management of Computers" parameter

\begin{tabular}{|c|c|c|c|c|}
\hline $\begin{array}{l}\text { Question } \\
\text { No. }\end{array}$ & Question & Option & Level & $\begin{array}{l}\text { Selected } \\
\text { Option by }\end{array}$ \\
\hline
\end{tabular}




\begin{tabular}{|c|c|c|c|c|}
\hline & & & & SME \\
\hline \multirow[t]{2}{*}{1} & \multirow{2}{*}{$\begin{array}{l}\text { Do you have practices to } \\
\text { turn off computers after } \\
\text { office hour? }\end{array}$} & a. Yes & 1 & $\checkmark$ \\
\hline & & b. No & 0 & \\
\hline \multirow[t]{4}{*}{2} & \multirow{4}{*}{$\begin{array}{l}\text { Which of the following } \\
\text { practices do you have in } \\
\text { case of inactivity? }\end{array}$} & a. Turn off & & \\
\hline & & b. Screen saver & 1 & \\
\hline & & c. Sleep & 2 & $\checkmark$ \\
\hline & & d. None of the above & 0 & \\
\hline \multirow[t]{5}{*}{3} & \multirow{5}{*}{$\begin{array}{l}\text { After how much time do } \\
\text { you put display and } \\
\text { system of computers into } \\
\text { sleep mode respectively? }\end{array}$} & $\begin{array}{l}\text { a. More than } 20 \text { minutes, } \\
\text { more than } 60 \text { minutes }\end{array}$ & 1 & \\
\hline & & $\begin{array}{l}\text { b. More than } 20 \text { minutes, } \\
30-60 \text { minutes }\end{array}$ & 2 & \\
\hline & & $\begin{array}{l}\text { c. } 5 \text { - } 20 \text { minutes, } 30-60 \\
\text { minutes }\end{array}$ & 3 & $\checkmark$ \\
\hline & & $\begin{array}{l}\text { d. } 5 \text { - } 20 \text { minutes, More } \\
\text { than } 60 \text { minutes }\end{array}$ & 4 & \\
\hline & & e. Don't know & 0 & \\
\hline \multirow[t]{2}{*}{4} & \multirow{2}{*}{$\begin{array}{l}\text { Do you use automated } \\
\text { software to turn off your } \\
\text { computers? }\end{array}$} & a. Yes & 4 & \\
\hline & & b. No & 3 & $\checkmark$ \\
\hline \multicolumn{2}{|c|}{$\begin{array}{l}\text { Aggregated Level for "Power } \\
\text { Management of Computers" }\end{array}$} & \multicolumn{3}{|c|}{3} \\
\hline
\end{tabular}

Table 5 presents the result for the "Power management of Computers" parameter. Four questions are formularized under this parameter. The target is to find Green ICT practice level for this parameter from the selected option for each of the questions. The level has been found by combining the texts of the selected options and matching them with the description of the level of this parameter in the framework presented in table-4. From that, the aggregated level for "Power management of Computers" parameter is 3. An example has been shown below in table 6 that displays different combination of selected option by users and the level for the above-mentioned scenario:

Table 6. A sample response of questions for "Power Management of Computers" parameter

\begin{tabular}{|c|c|c|c|c|c|}
\hline & Question 1 & Question 2 & Question 3 & Question 4 & Level \\
\hline Option & $\mathrm{a}$ & c & $\mathrm{C}$ & $\mathrm{b}$ & \\
\hline $\begin{array}{l}\text { Description } \\
\text { of selected } \\
\text { options }\end{array}$ & $\begin{array}{l}\text { Computers are } \\
\text { turned off after } \\
\text { office hour }\end{array}$ & $\begin{array}{l}\text { During } \\
\text { inactivity sleep } \\
\text { mode is active } \\
\text { on computers }\end{array}$ & $\begin{array}{l}\text { Time for } \\
\text { putting } \\
\text { display and } \\
\text { the system into } \\
\text { sleep mode are } \\
\text { after 5-20 } \\
\text { minutes and } \\
\text { 30-60 minutes } \\
\text { respectively. }\end{array}$ & $\begin{array}{l}\text { No automated } \\
\text { software is } \\
\text { used inside the } \\
\text { SME to turn } \\
\text { off computers } \\
\text { automatically }\end{array}$ & 3 \\
\hline
\end{tabular}

After calculating level for each of the eight parameters in the way mentioned above, the mode operation is performed to provide an overall green ICT practice level of the SME. Mode operation is chosen for detecting the aggregated level because it provides the most frequently appeared level. 
Moreover, since an SME can be in different level for different parameters, therefore it is difficult to provide an exact level from those parameter wise levels. Hence, mode operation is performed to provide an overall green ICT practice level to SME. Table 7 presents an example for the eight parameters out of which four of the parameters are in level " 1 ". According to mode operation, the aggregated level for the above scenario is " 1 ". In the application, a detailed list of current situations of green ICT practices are provided at the end of the test in the application. It displays the current level of green ICT practices and provides a tag line (such as, Novice, Beginner, Expert and many others) to indicate level 0 to 4 respectively. It aware end-users about their current level and encourages for improvement (see Figure 3).

Table 7. Scenario for Green ICT practice levels for different parameters for an SME

\begin{tabular}{ll}
\hline Parameter & Green ICT Practice Level \\
\hline Power management of computers & 1 \\
\hline Reduction of computers for power management & 1 \\
\hline Power Management of Imaging Equipment & 1 \\
\hline Paper saving from ICT equipment & 1 \\
\hline Power management of video conferencing suite & 2 \\
\hline IT Load Reduction Management of Server & 3 \\
\hline Cooling management of ICT equipment & 2 \\
\hline Management of E-waste disposal & 0 \\
\hline Aggregated/Final Level & $\mathbf{1}$ \\
\hline
\end{tabular}




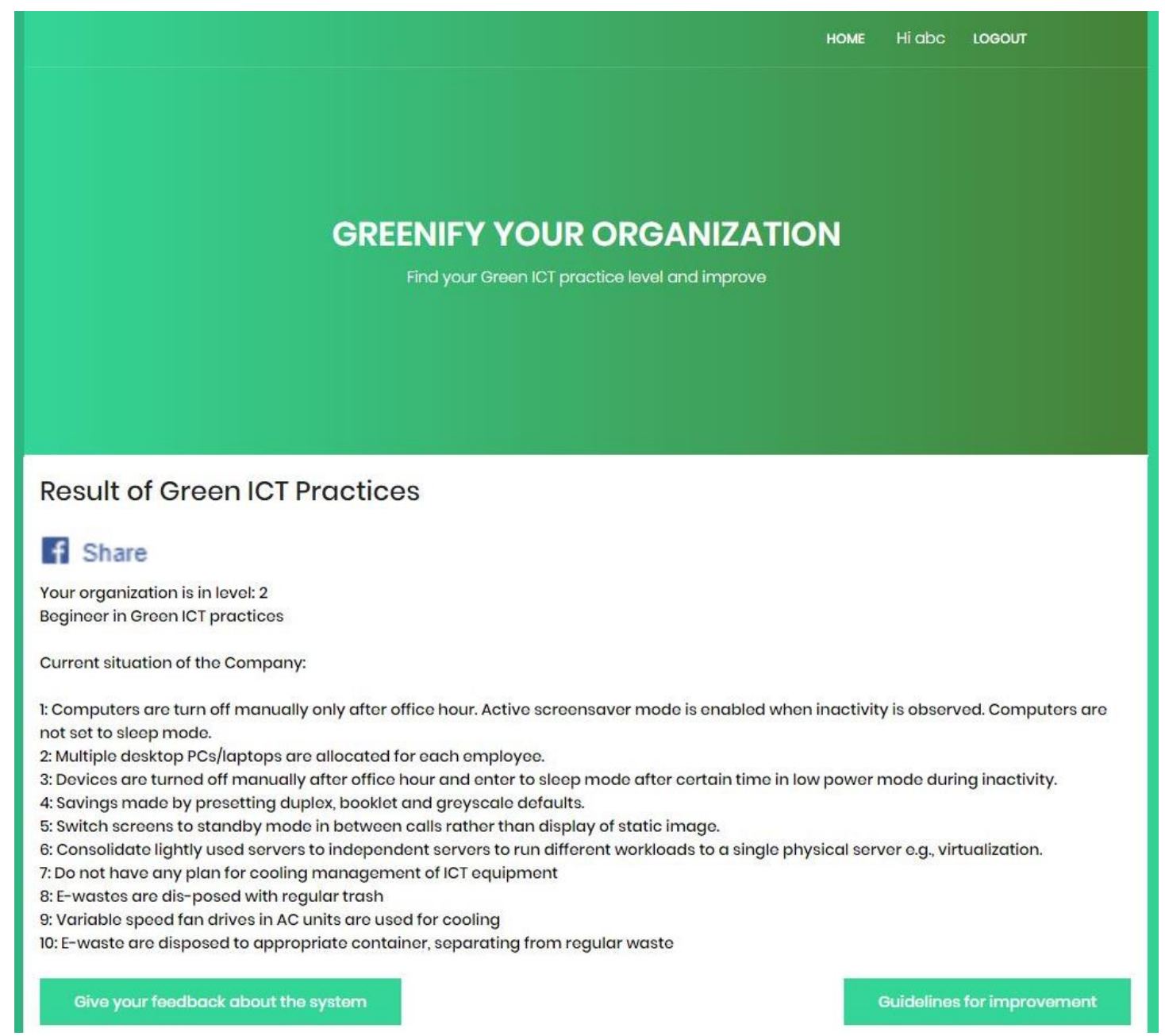

Figure 3. Detailed list of practices for Green ICT situation of an SME

Upon detecting the level for Green ICT practices, a comparison has been made with other SMEs who already took the test through this application. For the other SMEs, the most frequently appeared level is determined as the overall level for all other SMEs. Based on the current level, guidelines for improvement are provided (see Figure 4). Improvement are suggested both parameter wise and overall. For the parameter wise improvement suggestions, at first the level is determined for that parameter. Then immediate actions are suggested to go to the next level for that specific parameter. However, different parameters can be in different levels and an SME can not go to the next level until it fulfills the all actions of its present level in each of the parameter. For that, an overall improvement suggestion is also provided to user for taking steps to go to the next level with the combination of all the parameters. 


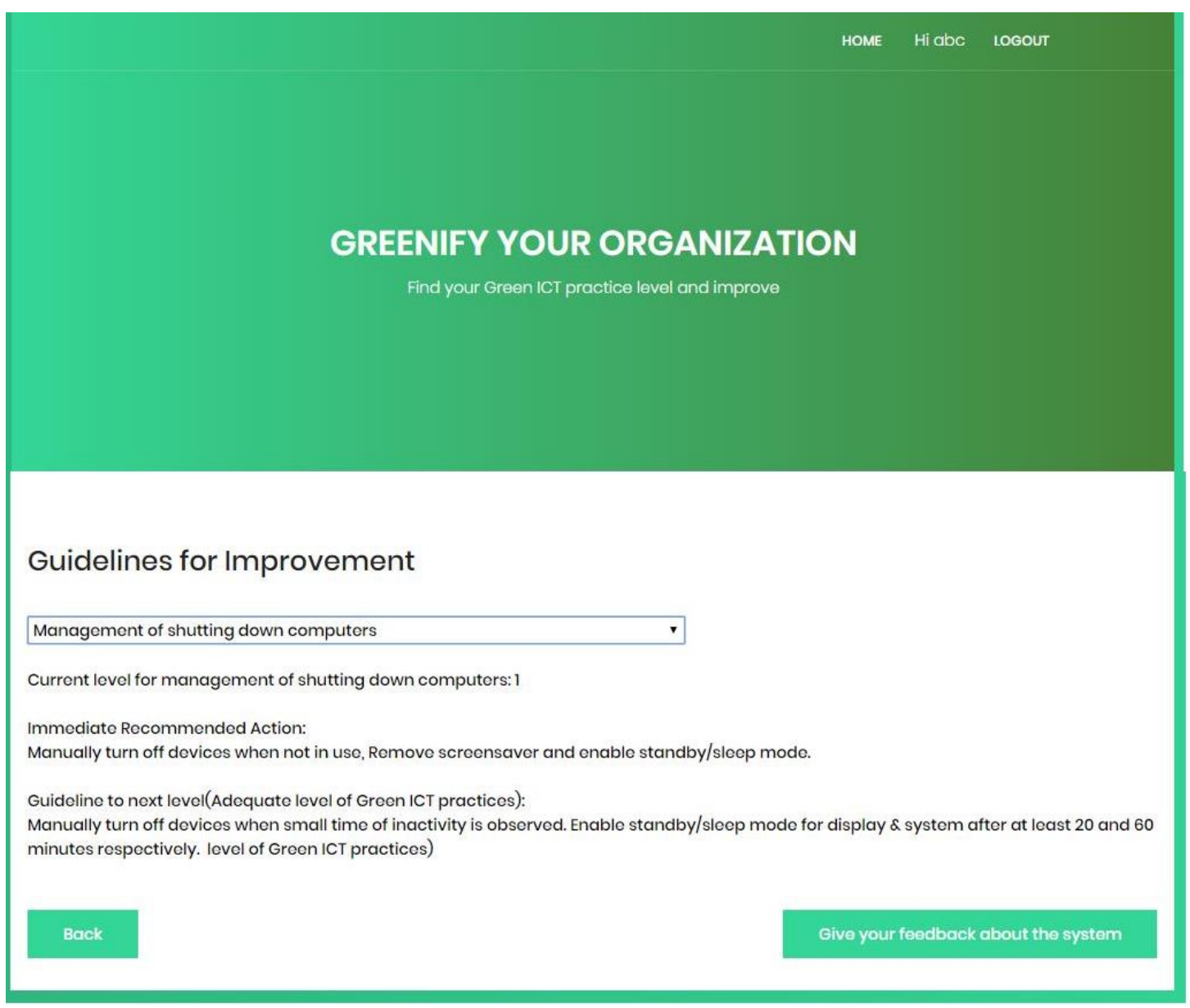

Figure 4. Parameter wise "Guidelines for Improvement" page

A special feature is included to share the status of Green ICT practices of an SME through social media such as Facebook. The reason behind including this feature is to provide a way to the SME so that the social image of the organization can be increased in the business community. The Facebook sharing feature can be found when a logged in user submits answers for each of the questions (see figure 3). Moreover, an user can take the test as many times he wants. He can track the records of previously taken test by clicking on the "See previous button" in the Home Page.

\section{Results and Discussions}

The GreenSME application has been tested in eight SMEs (four in Finland and four in Bangladesh) by the IT specialists. The number of employees in the start-up companies are around 10-12 and in the regular sized SMEs are around 50-100. The SMEs are software companies. At first online interviews have been conducted with SMEs to know the basic information such as, organization's employee size, problems and goals of their business etc. However, organizations identities are kept anonymous for this research. Next, a request with website link of the application has been sent to the organizations to participate in the testing. This request has been sent through e-mail to several organizations. Table 8 presents the research demographics. SME 1 and 2 are medium sized organizations in Finland, where number of employees are less than 250. SME 3 and 4 have employees about less than 50, therefore they are small-sized enterprises. On the other hand, SME $5 \& 6$ are medium sized and SME $7 \& 8$ are small sized enterprises, where the number of employees is less than 50 and 150 respectively. The results have been analyzed in the context of green ICT practices in i.e. developed and developing countries.

Table-8. Results from the SMEs 


\begin{tabular}{|c|c|c|c|c|c|c|c|c|}
\hline \multirow{2}{*}{$\begin{array}{ll} & \text { Country } \\
\text { SMEs } & \end{array}$} & \multicolumn{4}{|c|}{ Finland } & \multicolumn{4}{|c|}{ Bangladesh } \\
\hline & SME 1 & SME 2 & SME 3 & SME 4 & SME 5 & SME 6 & SME 7 & SME 8 \\
\hline Number of Employees & 72 & 100 & 15 & 35 & 65 & 90 & 12 & 20 \\
\hline $\begin{array}{l}\text { Power Management of } \\
\text { Computers }\end{array}$ & 2 & 2 & 2 & 2 & 2 & 2 & 1 & 1 \\
\hline $\begin{array}{l}\text { Reduction of number } \\
\text { of computers for } \\
\text { power management }\end{array}$ & 2 & 3 & 1 & 2 & 1 & 1 & 1 & 1 \\
\hline $\begin{array}{l}\text { Power Management of } \\
\text { Imaging Equipment }\end{array}$ & 3 & 3 & 1 & 1 & 2 & 1 & 0 & 1 \\
\hline $\begin{array}{l}\text { Paper Saving from ICT } \\
\text { equipment }\end{array}$ & 2 & 3 & 1 & 1 & 2 & 2 & 0 & 0 \\
\hline $\begin{array}{l}\text { Power Management of } \\
\text { Video Conferencing } \\
\text { Suite }\end{array}$ & 2 & 2 & 0 & 0 & 0 & 1 & 0 & 0 \\
\hline $\begin{array}{l}\text { IT Load Reduction } \\
\text { Management of Server }\end{array}$ & 1 & 0 & 1 & 0 & 0 & 0 & 0 & 0 \\
\hline $\begin{array}{l}\text { Cooling Management } \\
\text { of ICT equipment }\end{array}$ & 2 & 3 & 0 & 1 & 0 & 0 & 0 & 0 \\
\hline $\begin{array}{l}\text { Management of } \\
\text { E-waste disposal }\end{array}$ & 1 & 2 & 1 & 1 & 0 & 0 & 0 & 0 \\
\hline $\begin{array}{ll}\text { Aggregated/ Final } \\
\text { Level }\end{array}$ & 2 & 3 & 1 & 1 & 0 & 0 & 0 & 0 \\
\hline
\end{tabular}

According to table-8, considering the first parameter "Power management of computers", most of the organizations $(1-6)$ are in level 2, which indicates that computers are turned off after office hour and put into sleep mode during inactivity. This feature is visible in regular and start-up SMEs in Finland. However, in Bangladesh, in the regular sized SMEs (5 \& 6), this practice is also observed. In the start-up companies in Bangladesh (7\& 8), the level is 1 for this parameter which means that though computers are turned off manually after office hour, instead of sleep, screensaver is set in case of inactivity.

On the other hand,, considering the last parameter, "Management of E-waste disposal" in Finland, which is a developed country, almost all organizations (SME 1, 3, 4) except SME 2 are in level 1, that means e-wastes are disposed into appropriate container, separating from the regular wastes where as in developing country, Bangladesh, e-wastes are disposed with regular wastes, often not disposed at all.

The aggregated or final level indicates that SMEs in Finland are in the higher level where SMEs in Bangladesh are in the lowest level of Green ICT practices. Though, in some cases, medium sized SMEs in Bangladesh are in the similar levels as the start-up or small sized enterprises, in Finland, considering all the parameters the overall or aggregated level for the SMEs in Bangladesh are still in very low level. To summarize, SMEs in developed countries like Finland possess better practices of Green ICT than developing countries like Bangladesh. According to [40], the main barriers for implementing green ICT in developing country is highlighted. According to survey conducted in the developing country, Kenya, the lack of green ICT trained human resource is found as the main barrier for implementing green ICT practices. The alternate hindrances to green ICT implementation inherited from the survey are incorporate absence of budget distribution to green ICT, lack of schemes for green ICT, absence of high management best administration bolster, absence of workshops and seminars for increase awareness about green ICT execution, dependence on donations for acquiring ICT equipment, quick changes of technologies, absence of knowledge about where to start for green ICT, presence of legistation that blocks execution of green ICT, general 
association protection from change, dread of inability to acknowledge noteworthy ecological effects etc [40].

- Survey Results about usability of GreenSME Application

After the 8 SMEs participated in the testing, a google survey form link has been sent to these SMEs to provide their feedback about the application.

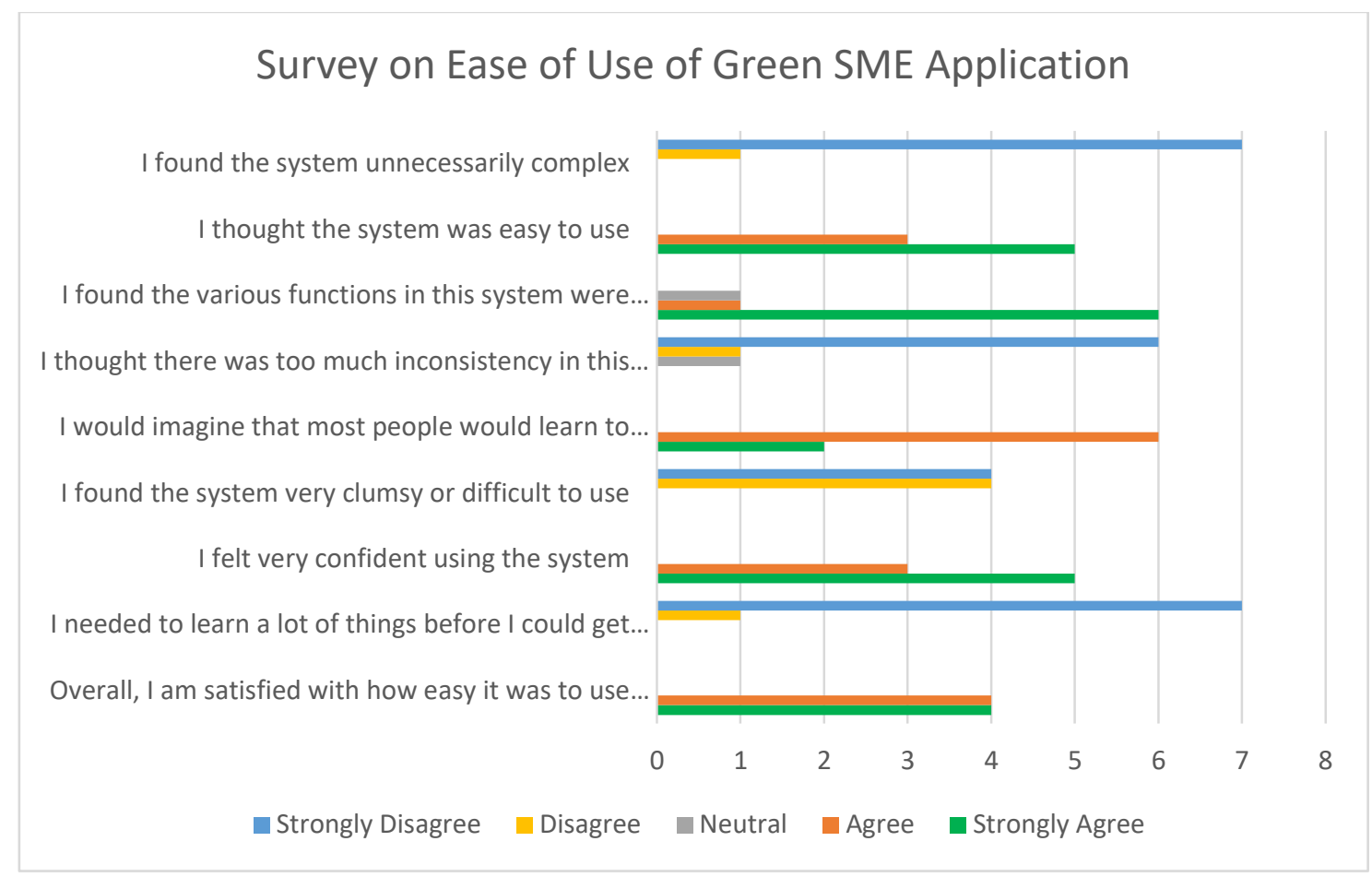

Figure 5. Survey about usability of GreenSME Application

The survey is conducted to understand the usability of the application. The responded found the application very easy to use. Moreover, they added that they need not to learn many things before using it. Overall, the participants provided positive responses about the ease of use of the application.

\section{- Survey Results about SME's Perception on sustainable aspects of GreenSME Application}

After the application has been tested by the SMEs, a survey has been conducted to understand SMEs' perception about the possibility to achieve sustainability through the GreenSME application. Survey questionnaire have been made to know whether by practicing the actions suggested in the application can provide economic, environmental and social benefits to sustain the business. Most of the SMEs believe the recommendation provided are helpful for reducing cost of their businesses and raising environmental awareness among employees to efficiently use ICT equipment. However, since some of the SMEs are in low level of Green ICT practices, neutral responses have been found about the social sustainability aspects of the application, for example, they may not want to publish their low levels Green ICT practice results in social media. 


\section{SME's Perception on sustainability aspect of GreenSME Application}

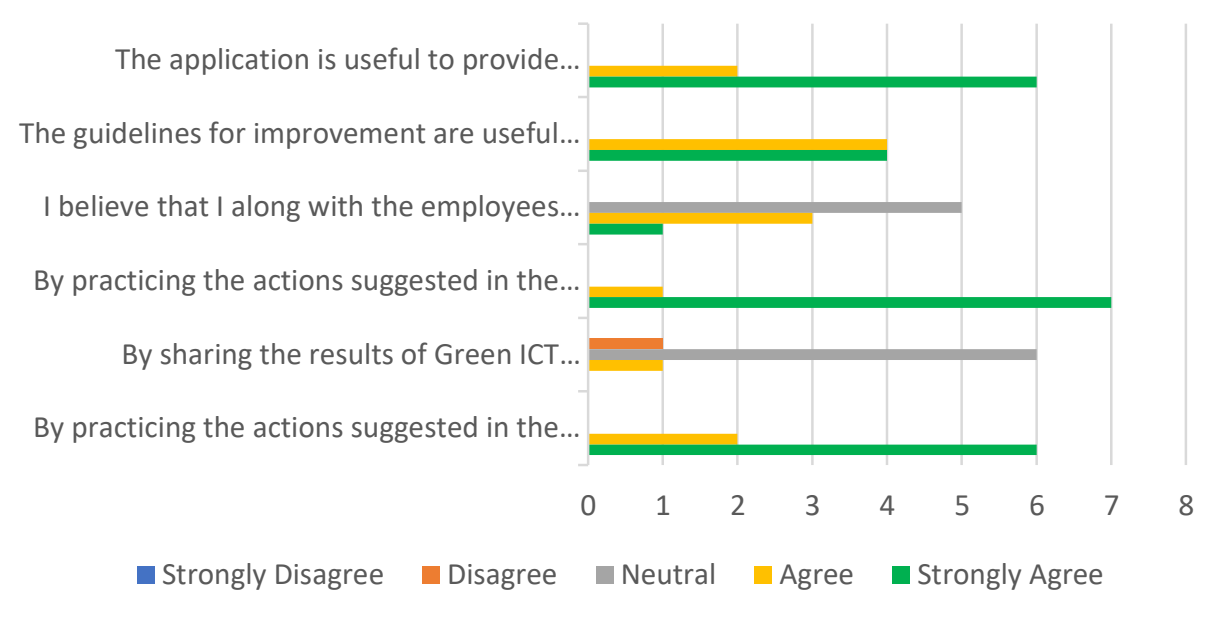

Figure 6. SME's perception on sustainability aspect of GreenSME Application

A sustainability analysis model was presented by Becker to analysis the systemic effects of a software on the five dimensions of sustainability [41]. The dimensions are, individual, environmental, technical, economic and social. From the individual perspective of sustainability, the application provides information about current situation of Green ICT practices in SMEs and guidelines for improvement, motivates to efficiently use ICT equipment, thus leads to a sustainable life-style. Moreover, by practicing the actions suggested in the application, raise environmental awareness among employees, which eventually contribute to reduce global warming. Therefore, the application can satisfy the environmental aspect of sustainability. From the social aspect, the application has possibilities to enable a sustainable business community by sharing the results of Green ICT practice level in social media. The goal of this application is to, motivate SMEs to efficiently use ICT equipment which could result in less electricity cost, consequently, reduces business costs. In addition, the application is developed in an extensible style which ensures the technical sustainability of the system. Thus, the application has positive impacts regarding individual, economic, environmental, social and technical aspects of sustainability.

\section{- Limitations}

The limitations of this research are given below:

- This research is limited to SMEs only.

- Scope of this research focuses mainly on ICT usage management in SMEs for a greener and sustainable future.

- The web application has been tested only by software companies.

\section{Conclusion}

This paper proposes a framework by mapping ICT green maturity level with the strategies that SMEs now-a-days are following for green ICT. A web application has been developed out of the framework for self-assessment and improvement of sustainable green ICT practices in SMEs. Results from the application provided by the participants in eight SMEs of Finland and Bangladesh, have been analyzed in the context of green ICT practices in developed and developing countries. Moreover, it has been found that due to the lack of Green ICT knowledge and practices, SMEs in developing countries exists in the low level of Green ICT practices than developed countries. Moreover, sustainability aspects of the application have been analyzed through survey. The result indicates that participants provided positive responses towards the prospects of sustainability of their business through this application. They believe that the information provided in this 
application is helpful for economic, environmental and social benefits to sustain their businesses. Moreover, according to the model provided in [41], the application satisfies individual, economic, environmental, social and technical aspects of sustainability.

Testing the application in different types of organizations and further analysis on providing improvement suggestion has left undone for future work.

\section{Supplementary Materials: None}

Author Contributions: Conceptualization, Jari Porras; Data curation, Farniba Khan; Funding acquisition, Farniba Khan and Jari Porras; Investigation, Farniba Khan; Methodology, Farniba Khan and Jari Porras; Project administration, Farniba Khan and Jari Porras; Resources, Farniba Khan and Jari Porras; Supervision, Jari Porras; Validation, Jari Porras; Visualization, Farniba Khan; Writing - original draft, Farniba Khan; Writing - review \& editing, Farniba Khan and Jari Porras.

Funding: This research was funded by PERCCOM Erasmus Mundus Program of the European Union grant number PERCCOM- FPA 2013-0231.

Acknowledgments: The authors would like to express their gratitude to all the partner institutions, sponsors, and researchers involved in the PERCCOM program [42].

Conflicts of Interest: The authors declare no conflict of interests

\section{References}

1. Hankel, A.; Heimeriks, G.; Lago, P. Green ICT Assessment for Organisations. Journal of ICT Standardization. 2017, vol. 4, no. 2, pp. 87-110.

2. Bazarhanova, A. A Belief Rule-Based Environmental Responsibility Assessment System for Small and Medium-Sized Enterprises. Leeds Beckett University. 2016.

3. Hevner, A. \& Chatterjee, S. Design Science Research in Information Systems, 2010. Available at: http://www.springerlink.com/index/10.1007/978-1-4419-5653

4. Global e-Sustainability Initiative (GeSI). \#SMARTer2030, ICT Solutions for 21st Century Challenges. Brussels: Global e-Sustainability Initiative (GeSI). 2015.

5. Desai, M.; Bhatia, V.; Kolli, S.; Raman, A. Assessing Green IT maturity and providing green IT recommendations, no. 19, 2013.

6. Bakker, F. D; Groenewegen, P. \& Hond, F. D. A Bibliometrical Analysis Of 30 Years Of Research and Theory On Corporate Social Responsibility and Corporate Social Performance. Business and Society. 2005. 44(3), 283-317.

7. Holmes, L.; Watts, R. Corporate Social Responsibility: Making Good Business Sense. World Business Council for Sustainable Development. 2000.

8. Michael, B. Corporate social responsibility in international development: an overview and critique. Corporate Social Responsibility and Environmental Management. 2003. vol. 10, no. 3, pp. 115-128.

9. Penzenstadler, B.; Bauer, V.; Calero, C.; Franch, X. Sustainability in Software Engineering: A Systematic Literature Review. 2012.

10. Yi-ling, Z. An Empirical Study on Corporate Social Responsibility and Corporate Profitability. 2011.

11. Corporate Social Responsibility: A business contribution to Sustainable Development. Commission of the European Communities. July 2002

12. Greener Computing. Green IT: why mid-size companies are investing now. 2009. Available at: https://www-03.ibm.com/press/attachments/GreenIT-final-Mar.4.pdf

13. Maneerat, P.; Malaivongs, K.; Khlaisang, J. The Comparison of Thai Qualification Framework for Higher Education and Capability Maturity Model Integration for Service. Procedia - Social and Behavioral Sciences. 2015, vol. 182, pp. 225-231.

14. Lautenschutz, D. Defining an auditing protocol to measure the maturity level of sustainable ICT in Utrecht University. 2018.

15. Donnellan, B.; Sheridan, C.; Curry, E. A capability maturity framework for sustainable information and communication technology. 2011, IT Prof. 13, 33-40.

16. Humphrey, W. Characterizing the software process: a maturity framework. IEEE Software. 1988, vol. 5, no. 2, pp. 73-79. 
17. Hynds, E.; Brandt, V.; Burek, S.; Jager, W.; Knox, P.; Parker, J.; Schwartz, L.; Taylor, J. and Zietlow, M. A Maturity Model for Sustainability in New Product Development. Research-Technology Management. 2014. vol. 57, no. 1, pp. 50-57.

18. Lautenschutz, D.; Espana, S.; Hankel, A.; Overbeek, S.; Lago, P. A Comparative Analysis of Green ICT Maturity Models. ICT4S2018. 5th International Conference on Information and Communication Technology for Sustainability. 2018, vol. 52, pp. 153-167.

19. Hankel, L.; Oud, M. S.; Lago, P. A maturity model for green ICT: The case of the SURF green ICT maturity model. EnviroInfo. 2018, pp. 33-40.

20. Molla, A.; Cooper, V.; Pittayachawan, S. The Green IT readiness (G-Readiness) of organizations: An exploratory analysis of a construct and instrument. Communications of the Association for Information Systems. 2011, vol. 291, pp. 67-96.

21. Foogooa, R.; Bokhoree, C.; Dookhitram, K. Green ICT Maturity Models Towards a general approach, 2015.

22. Greenhouse Gas Protocol. Calculation Tools. Available online: http://www.ghgprotocol.org/calculation-tools/all-tools. [Accessed 9 December 2013].

23. Carbon Footprint, Free Carbon Footprint Calculators. Available online: http://www.carbonfootprint.com/calculator1.html. [Accessed 9 December 2013].

24. The Carbon Neutral Company. Business Carbon Calculators. Available online: http://www.carbonneutral.com/our-services/channel-partners/carbon-calculators/. [Accessed 9 December 2013].

25. Silvius, A. A Maturity Model for Integrating Sustainability in Projects and Project Management. 24th World Congress of the International Project Management Association (IPMA). 2010.

26. Klimova, A. Systematic Literature Review of Using Knowledge Management Systems and Processes in Green ICT and ICT for Greening. In: Dastbaz M., Arabnia H., Akhgar B. (eds) Technology for Smart Futures. 2018. Springer, Cham.

27. Khakurel, J.; Melkas, H.; Porras, J. Tapping into the wearable device revolution in the work environment: a systematic review. Information Technology \& People. 2018. vol. 31, no. 3, pp. 791-818.

28. Global Action Plan. Green ICT Handbook: A Guide to Green ICT. 2009, pp. 1-28.

29. Wyse Technology Inc. Desktop Energy Consumption a Comparison of Thin Clients and PCs. Available online: http://thinclient.org/archives/wyse-energy_study.pdf

30. The State Electronics Challenge. Northeast Recycling Council (NERC). Saving energy with office equipment. Available

http://stateelectronicschallenge.net/pdf/sec_computer_power_management_guide.pdf

31. Ranbhise, P. Green Computing A way towards environmentally sustainable future. 2014. International Conference on Contemporary Computing and Informatics (IC3I), no. 2014, pp. 1094-1100, 2008.

32. Murugesan, S.; Gangadharan, G. Harnessing Green IT. Hoboken: Wiley [Imprint]. 2012.

33. Samoei, P.; Chepkoech, I.; Christopher, M. A university of Nairobi college of biological and physical science. An Assessment of Green ICT Effect on Sustainable Environment in Institutions of Higher Learning in Kenya. 2016 IEEE/ACIS 14th International Conference on Software Engineering Research, Management and Applications, SERA. 2016.

34. Shaw, J.; Kor, A.; Pattinson, C. An Evaluation of the Impact of Remote Collaboration Tools on Corporate Sustainability. 2016 IEEE 14th Intl Conf on Dependable, Autonomic and Secure Computing. 14th Intl Conf on Pervasive Intelligence and Computing. 2nd Intl Conf on Big Data Intelligence and Computing and Cyber Science and Technology Congress An. pp. 257-262, 2016.

35. Energy Star. Top 12 ways to decrease the energy consumption of your data center. Available online: https://www.energystar.gov/sites/default/files/asset/document/DataCenter-Top12-Brochure-Final.pdf

36. Kasbun, R.; Adnan, A.; Khalid, N.; Jaafar, H. Green ICT Practices and Challenges: Electronic Waste Disposals Steps Awareness in Overcoming Environmental Erosion. International Conference on Information Technology and Multimedia 2016. IC-ITM 2016. 2016.

37. Jaiswal, A.; Samuel, C.; Patel, B.; Kumar, M. Go Green with WEEE: Eco-friendly Approach for Handling E- waste. Procedia Computer Science. 2015. vol. 46, pp. 1317-1324.

38. Sambhanthan, A. Potdar, V. Business sustainability frameworks a survey. 2016. pp. 171-177.

39. Available online :https:/www.surveymonkey.com/wpcontent/uploads/2014/07/ Survey_Writing_Guide1.pdf. [Accessed: 17- Jul- 2018].

40. Wabwoba, F.; Wanyembi, G.; Omuterema, S. Barriers to Implementation of Green ICT in Kenya. 2012. 
41. Becker, C.; Betz, S.; Chitchyan, R.; Duboc, L.; Easterbrook, S.; Penzenstadler, B.; Seyff, N.; Venters, C. Requirements: The Key to Sustainability. IEEE Software. 2016. vol. 33, no. 1, pp. 56-65.

42. Porras, J.; Seffah, A.; Rondeau, E.; Andersson, K.; Klimova, A. PERCCOM: A Master Program in Pervasive Computing and COMmunications for Sustainable Development. 29th IEEE Conference on Software 